\title{
Emissions of Airborne Toxics from Coal-Fired Boilers: Mercury
}

by H.S. Huang, C.D. Livengood, and S. Zaromb*

Energy Systems Division,

Argonne National Laboratory, 9700 South Cass Avenue, Argonne, ii.'inois 60439

September 1991

Work sponsored by United States Department of Energy,

Assistant Secretary for Fossil Energy, Pittsburgh Energy Technology Center

"Zaromb is affiliated with Argonne's Environmental Research Division. 


\section{CONTENTS}

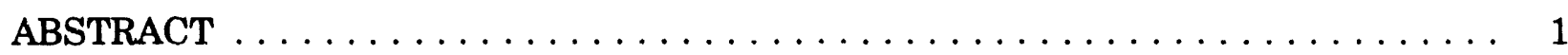

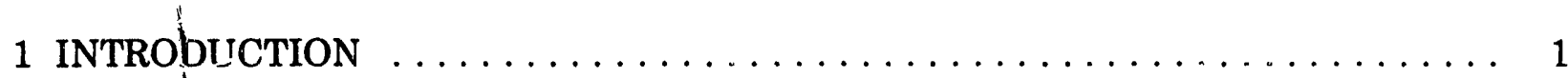

¿ CONCEYNTRATION OF MERCURY IN U.S. COALS $\ldots \ldots \ldots \ldots \ldots \ldots \ldots$

3 MERCURY EMISSIONS FROM COALCOMBUSTION SYSTEMS $\ldots \ldots \ldots \ldots$. 5

3.1 Conventional Coal-Fired Combustors $\ldots \ldots \ldots \ldots \ldots \ldots \ldots \ldots \ldots$

3.2 Fluidized-Bed Combustors $\ldots \ldots \ldots \ldots \ldots \ldots \ldots \ldots \ldots \ldots$

4 INFLUENCE OF FLUE-GAS-CLEANING DEVICES ON MERCURY

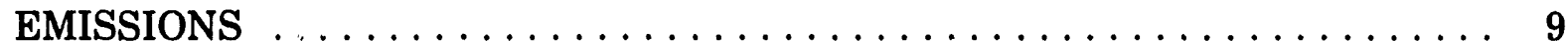

4.1 Particulate-Collection Devices $\ldots \ldots \ldots \ldots \ldots \ldots \ldots \ldots \ldots \ldots \ldots$

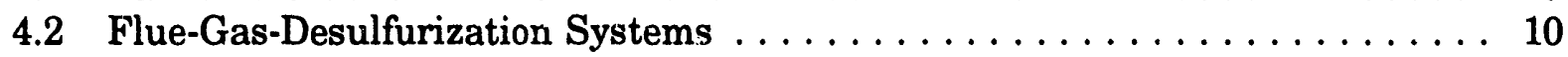

5 NEW PROCESSES FOR CONTROL OF MERCURY EMISSIONS . . . . . . . . 13

5.1 Improved Spray-Drying Scrubbing System $\ldots \ldots \ldots \ldots \ldots \ldots \ldots \ldots$

5.2 Polysulfide Wet Scrubbing Process $\ldots \ldots \ldots \ldots \ldots \ldots \ldots \ldots \ldots \ldots \ldots \ldots$

5.3 Low-Temperature Plasma Process $\ldots \ldots \ldots \ldots \ldots \ldots \ldots \ldots \ldots \ldots$

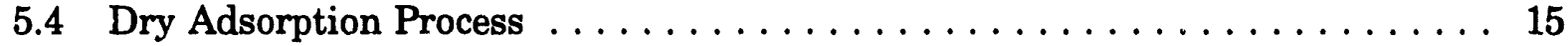

6 CONCLUSIONS AND RECOMMENDATIONS $\ldots \ldots \ldots \ldots \ldots \ldots \ldots \ldots$

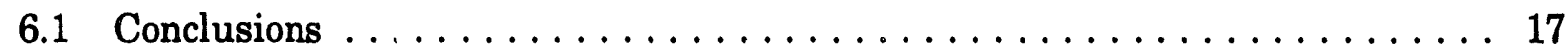

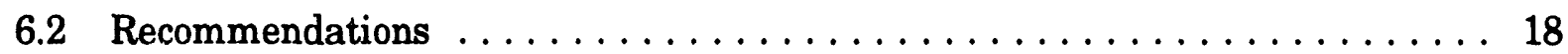

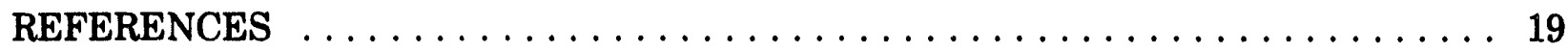

APPENDIX: Review of Sampling and Analysis Methods for Emissions

of Mercury and Its Compounds from Coal-Burning Facilities

\section{FIGURES}

1 Efficiency of Mercury Vapor Removal from Incinerator Flue Gas by the Low-Temperature Plasma Process $\ldots \ldots \ldots \ldots \ldots \ldots \ldots \ldots$

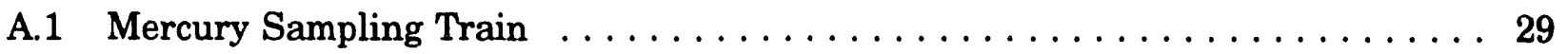

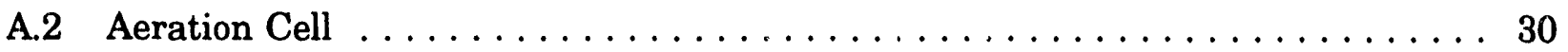




\section{FIGURES (Cont.)}

A.3 Schematic of Aeration System $\ldots \ldots \ldots \ldots \ldots \ldots \ldots \ldots \ldots$

A.4 Optical Cell $\ldots \ldots \ldots \ldots \ldots \ldots \ldots \ldots \ldots \ldots \ldots \ldots \ldots \ldots \ldots \ldots \ldots$

\section{TABLES}

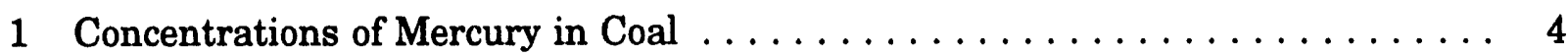

2 Ranges of Mercury Concentrations in Coal $\ldots \ldots \ldots \ldots \ldots \ldots \ldots$

3 Concentrations of Mercury in Coal by U.S. Region . . . . . . . . . . . 4

4 Ranges of Mercury Emissions from Coal-Fired Boilers $\ldots \ldots \ldots \ldots \ldots \ldots$

5 Summary of Mercury Removal Efficiencies from Coal-Fired Boiler Emissions $\ldots \ldots \ldots \ldots \ldots \ldots \ldots \ldots \ldots \ldots \ldots \ldots \ldots$

6 Mercury Removal in Tests with SDA Systems $\ldots \ldots \ldots \ldots \ldots \ldots \ldots$ 


\title{
EMISSIONS OF AIRBORNE TOXICS FROM COAL-FIRED BOILERS: MERCURY
}

by

\author{
H.S. Huang, C.D. Livengood, and S. Zaromb
}

\begin{abstract}
Concerns over emissions of hazardous air pollutants (air toxics) have emerged as a major environmental issue, and the authority of the U.S. Environmental Protection Agency to regulate such pollutants was greatly expanded through the Clean Air Act Amendments of 1990. Mercury has been singled out for particular attention because of concerns over possible effects of emissions on human health. This report evaluates available published information on the mercury content of coals mined in the United States, on mercury emitted in coal combustion, and on the efficacy of various environmental control technologies for controlling airborne emissions. Anthracite and bituminous coals have the highest mean-mercury concentrations, with subbituminous coals having the lowest. However, all coal types show very significant variations in mercury concentrations. Mercury emissions from coal combustion are not vellcharacterized, particularly with regard to determination of specific mercury compounds. Variations in emission rates of more than an order of magnitude have been repor ted for some boiler types. Data on the capture of mercury by environmental control technologies are available primarily for systems with electrostatic precipitators, where removals of approximately $20 \%$ to over $50 \%$ have been reported. Reported removals for wet flue-gasdesulfurization systems range between 35 and $95 \%$, while spraydryer/fabric-filter systems have given removals of 75 to $99 \%$ on municipal incinerators. In all cases, better data are needed before any definitive judgments can be made. This report briefly reviews several areas of research that may leac' to improvements in mercury control for existing fluegas-cleanup technologies and summarizes the status of techniques for measuring mercury emissions from combustion sources.
\end{abstract}

\section{INTRODUCTION}

Public concern over exposure to hazardous air pollutants (air toxics) has emerged as one of the major environmental issues since the 1980s. ${ }^{1-6}$ Under Section 112 of the Clean Air Act Amendments, the U. S. Environmental Protection Agency (EPA) has been required to promulgate emission standards for those air pollutants that are not regulated under 
National Ambient Air Quality Standards. To date, EPA has prescribed actual emission standards for only seven substances (arsenic, asbestos, benzene, beryllium, mercury, radionuclides, vinyl chloride) and one source (coke oven emissions). Additionally, EPA previously determined that the low risks associated with radionuclide emissions from fossil fuel power plants did not justify regulation under Section 112. However, EPA may have to reconsider this decision under the so-called "residual risk" provisions of Section $112(\mathrm{f})$ in the latest amendments to the Clean Air Act.

The Clean Air Act Amendments of 1990 greatly expanded EPA's rulemaking authority over hazardous air pollutants. The law lists 189 chemical compounds that would be subjected to control. For stationary sources that emit 10 ton/yr or more of any one of the listed pollutants, or 25 ton/yr or more of any combined emissions, the maximum available control technology (MACT) must be applied. By definition, the MACT is at least as stringent as the best available control technology (BACT) for similar sources. In addition, the new amendments represent a major shift in approach from regulation of hazardous air pollutants using health-based, substance-specific standards to regulation under technology-based standards applicable to categories of emission sources rather than to the substances themselves. The new amendments also state that the cust and feisibility of control, energy impacts, and environmental factors will be taken into consideration in the application of the MACT.

Under the new amendments, the EPA is directed to conduct a three-year study of the public health hazards from exposure to toxic emissions from utilities and to report the results to the Congress. EPA can regulate such emissions only if the limitations are determined to be appropriate on the basis of this study. Two additional studies that specifically address mercury emissions are also required. In the first, EPA is directed to conduct a four-year study of inercury emissions from electric utility steam-generation plants, municipal-waste incineration plants, and other sources. Included in this study are evaluations of the rate and mass of such emissions, their health and environmental effects, and the available control technologies and their costs. The second study directs the National Institute of Environmental Health Sciences to study the threshold level of mercury exposure that would affect human health. However, EPA is directed not to regulate these emissions until the studies are completed, and in no event are regulations to be established sooner than three years or later than five years after the legislation has been enacted.

This report summarizes the information available on mercury emissions from coalfired boilers. Also included in this report is an overview of the sampling and analytical techniques that have been employed for determination of mercury emissions in the stack. 


\section{CONCENTRATION OF MERCURY IN U.S. COALS}

Information available before 1972 on trace elements in coal is compiled in a report by Magee et al., ${ }^{7}$ which contains extensive earlier results published by researchers at the U.S. Geological Survey (USGS) and the U.S. Bureau of Mines (USBM). However, as pointed out by Ruch and his coworkers at the Illinois State Geological Survey (ISGS), there is a serious shortcoming in these earlier studies:

Trace element investigations in coal prior to 1970 were based on analyses of high-temperature ash, which measure the oxides of the elements in the altered mineral matter. Although such investigations are valuable for estimating concentrations of refractive constituents, or elements of low volatility, they do not reliably measure total amounts of volatile elements in whole coal ...8

The most thorough effort to determine the trace-element content of U.S. coals undoubtedly has been the coal geochemistry program of the U.S. Geological Survey. In collaboration with the Bureau of Mines, the USTS has analyzed a great number of samples from hundreds of coal beds in the United States. The results have been entered into the U.S. National Coal Resources Data Systems. These results, which have been evaluated and reported, ${ }^{7-15}$ are summarized below.

The mean concentrations of mercury in U.S. coal by coal type are given in Table 1. Bituminous and anthracite coals have the highest mean mercury concentrations, $0.21 \mathrm{ppm}$ and $0.23 \mathrm{ppm}$, respectively. These numbers may be considered as typical values for U.S. coals, because the data from U.S. National Coal Resources Data Systems were used in the statistical data reduction. Also shown in the table is that the standard deviation either exceeds or approaches the mean, indicating strong variations in the data. Subbituminous coals have the greatest range of reported mercury concentrations (Table 2).

The concentrations of mercury in U.S. coal also vary according to the geographic region in which the coal is mined. Coals from the Appalachian and Gulf states have the highest mean concentrations, whereas coals from the Alaska region have the lowest (Table 3). However, coals from the Alaska region also have the greatest range of mercury concentrations, from $0.02 \mathrm{ppm}$ to as high as $63 \mathrm{ppm}$.

Mercury is consistently found in the inorganic portion of the coal structure. ${ }^{7-12}$ Kuhn and coworkers at the ISGS ${ }^{11}$ reported that suifides are the principal inorganic minerals commonly associated with mercury in coal. These observations point to the possibility of significantly reducing the mercury level in coal through physical coal-preparation processes. 
TABLE 1 Concentrations of Mercury in Coal

\begin{tabular}{lccc}
\hline & & \multicolumn{2}{c}{ Concentration (ppm) } \\
\cline { 3 - 4 } Coal Type & $\begin{array}{c}\text { Number } \\
\text { of Samples }^{\mathrm{a}}\end{array}$ & Mean $^{\mathrm{a}}$ & $\begin{array}{c}\text { Standard } \\
\text { Deviation }^{2}\end{array}$ \\
\hline Lignite & 183 & 0.15 & 0.14 \\
Subbituminous & 640 & 0.10 & 0.11 \\
Bituminous & 3527 & 0.21 & 0.42 \\
Anthracite & 52 & 0.23 & 0.27 \\
\hline
\end{tabular}

a Data from Ref. 10.

TABLE 2 Ranges of Mercury Concentrations in Coal

\begin{tabular}{lr}
\hline \multicolumn{1}{c}{ Coal Type } & \multicolumn{1}{c}{ Range $^{\mathrm{a}}$} \\
\hline Lignite & $0.03-1.0$ \\
Subbituminous & $0.01-8.0$ \\
Bituminous & $<0.01-3.3$ \\
Anthracite & $0.16-0.3$ \\
\hline
\end{tabular}

ata from Ref. 9.

TABLE 3 Concentrations of Mercury in Coal by U.S. Region

\begin{tabular}{lccc}
\hline & \multicolumn{3}{c}{ Mercury Concentration (ppm) } \\
\cline { 2 - 4 } \multicolumn{1}{c}{ Region } & Range & $\begin{array}{c}\text { Arithmetic } \\
\text { Mean }\end{array}$ & $\begin{array}{c}\text { Standard } \\
\text { Deviation }\end{array}$ \\
\cline { 2 - 4 } Appalachian & $<0.01-3.3$ & 0.24 & 0.47 \\
Interior & $0.01-1.5$ & 0.14 & 0.14 \\
Illinois Basin & $0.03-1.91$ & 0.21 & 0.22 \\
Gulf Province & $0.03-1.0$ & 0.24 & 0.19 \\
Norkiern Plains & $0.01-3.8$ & 0.11 & 0.10 \\
Rocky Mountains & $0.01-8.0$ & 0.09 & 0.12 \\
Alaska & $0.02-63$ & 0.08 & 0.07 \\
\hline
\end{tabular}

Source: Ref. 9. 


\section{MERCURY EMISSIONS FROM COAL-COMBUSTION SYSTEMS}

During combustion, trace elements in the coal entering the furnace are released and partitioned between the bottom ash and the flue gas, which contains suspended fly-ash particles and the vapors of such volatile elements as mercury, arsenic, and boron. As the flue gas cools to $370-430^{\circ} \mathrm{C}$ in the convective heat-transfer section and further (to about $150^{\circ} \mathrm{C}$ ) in the air preheater, a portion of the less volatile elements condenses on the surface of the fly-ash particles. Because of this vaporization and condensation, an inverse dependence of the concentration of many volatile elements on the size of the fly-ash particles has been observed. ${ }^{16-19}$

Modern coal-fired boilers are equipped with particulate-control and flue-gasdesulfurization devices in response to environmental concerns. As the fly-ash-laden flue gas enters these devices, trace elements are further partitioned, and further condensation of the volatile elements can occur in these gas-treatment systems. Elements on large fly-ash particles are retained by the particulate-collection devices, whereas elements on small particles or in vapor form that escape the control devices are discharged into the atmosphere. Therefore, the distribution of trace olements is influenced by the type of boiler, the operating conditions, and the flue-gas-cleaning system, as well as by the concentration of the elements in the coal.

Three classifications of the elements according to their partitioning and enrichment in a pulverized-coal-fired power plant have been proposed and used to characterize their emissions. ${ }^{9,18}$ Class I elements are of low volatility even at high temperatures $\left(1200-1600^{\circ} \mathrm{C}\right)$ and have no tendency to concentrate in or on fly-ash particles. Class II elements are vaporized but then 'econdensed, tending to concentrate in or on fly-ash particles, and these elements are depleted in the bottom ash and slag. Class III elements are those remaining mostly in the vapor phase, and they may be emitted from the stack even though the combustion system is equipped with a conventional flue-gas-cleaning device. Among the Class III elements are mercury, boron, chlorine or hydrogen chloride, and fluorine (r) hydrogen fluoride. To accommodate the observation that some elements behave as either Class I or Class II in different investigations, an additional intermediate classification (Class I/II) has been proposed.

A study conducted by Coutant et al. of the Battelle-Columbus Laboratories on four coal samples in a pilot-scale combustor indicated that mercury is transmitted through the combustion system with little retention in the slag or higher-temperature ash deposits. ${ }^{19}$ Appreciable retention of mercury was noticed in the precipitator samples of all but one coal, and the remainder of the mercury was associated with the fly-ash and gaseous samples taken in the stack. A very small (but consistent) occurrence of mercury in the slag was also identified during the tests and was attributed to physical trapping of mercury in the glass deposits during the slag-solidification stage. 


\subsection{CONVENTIONAL COAL-FIRED COMBUSTORS}

In terms of conventional coal-fired boilers, the utility sector in the United States is dominated by pulverized-coal (PC) dry-bottom units. Wet-bottom and cyclone boilers are no longer sold due to the difficulty in meeting nitrogen oxides $\left(\mathrm{NO}_{\mathrm{x}}\right)$ emission standards, and stoker boilers account for a small percentage of the total. In the industrial sector, stoker (mainly spreader-type) and small PC dry-bottom units account for most of the coal-fired plants. This is similar to the case for larger boilers in the commercial/institutional sector, but in this sector oil- and natural-gas-fueled boilers dominate the total mix of units.

Emission factors for trace elements, including mercury, for coal-and oil-combustion sources in the utility, industrial, commercial/institutional, and residential sectors have been evaluated and summarized in an EPA report prepared by Radian Corporation. ${ }^{9}$ The utility and industrial sectors are the best-characterized combustion sources, while relatively few data are available for the commercial/institutional and residential sectors. In this subsection, we present information from the Radian report and other reports on mercury emissions from. coal-fired utility and irdustrial boilers. Note that "since insufficient data are available to develop statistical estimates of the accuracy of these emission factors, no estimate can be made of the error that could result when these factors are used to calculate emissions from any given facility." 9 For mercury emissions, an additional uncertainty is that the literature is not always clear on whether the measured values were total mercury, vapor-phase mercury, or mercury condensed on particulate matter.

Furthermore, a major deficiency in prior field experiments measuring mercury in the flue gas from coal-combustion systems is that very few determinations were made of the types of mercury compounds present. Since some mercury compounds, notably dimethyl and monomethyl mercury compounds, are much more toxic than others, the lack of information on the concentrations of individual mercury compounds in the flue gas make a credible risk assessment impossible. Idditionally, the sampling and analytical methods used in previous investigations may have been unreliable. (Sampling and analytical techniques are discussed in the appendix to this report.)

Information on measured mercury emissions from coal-fired utility and industrial boilers is summarized in Table 4 for bituminous, subbituminous, and lignite coals. Since mercury is one of the most volatile elements present in coal, esse'stially $100 \%$ of it is volatilized in conventional combustors. The form of mercury present in the flue gas after combustion depends on temperature and on fly-ash characteristics. The literature indicates that the greater portion of the mercury is emitted in the vapor phase; however, the proportion of mercury measured in fine particulate matter vs. the vapor phase varies greatly between tests. Often the mass balances do not close well, and there exist significant differences in measured mercury emissions between tests. Information on the distribution of mercury between the vapor and particulate phases can be used to determine whether particulatecontrol devices will be effective for mercury control. 
TABLE 4 Ranges of Mercury Emissions from Coal-Fired Boilers (lb/10 ${ }^{12}$ Btu)

\begin{tabular}{|c|c|c|c|}
\hline \multirow[b]{2}{*}{ Boiler Type } & \multicolumn{3}{|c|}{ Coal } \\
\hline & Bituminous & Subbituminous & Lignite \\
\hline \multicolumn{4}{|l|}{ Utility } \\
\hline \multicolumn{4}{|l|}{ Pulverized-coal dry-bottom } \\
\hline Uncontrolled & $3.9-308$ & $--^{a}$ & -- \\
\hline With multiclone & -- & -- & $4.4-6.5$ \\
\hline With ESP & $0.4-22$ & 4.1 & $<0.23$ \\
\hline \multicolumn{4}{|l|}{ Pulverized-coal wet-bottom } \\
\hline Uncontrolled & -- & -- & -- \\
\hline With ESP & $2.6-6.3$ & -- & -- \\
\hline \multicolumn{4}{|l|}{ Cyclone furnace } \\
\hline Uncontrolled & 10 & 81 & -- \\
\hline With scrubber & -- & 4.9 & -- \\
\hline With ESP & $4.0-18$ & -- & 0.46 \\
\hline With cyclone & -- & -- & 22 \\
\hline \multicolumn{4}{|l|}{ Spreader-stoker } \\
\hline Uncontrolled & -- & -- & -- \\
\hline With multiclone & -- & -- & 5.6 \\
\hline With ESP & - & -- & 0.53 \\
\hline \multicolumn{4}{|l|}{ Industrial } \\
\hline \multicolumn{4}{|l|}{ Pulverized-coal dry-bottom } \\
\hline Uncontrolled & -- & -- & -- \\
\hline With ESP & $4.2-4.4$ & $\cdots$ & -- \\
\hline \multicolumn{4}{|l|}{ Spreader-stoker } \\
\hline Uncontrolled & $0.8-12$ & $0.6-17$ & -- \\
\hline With multiclone & $5.8-25$ & -- & -. \\
\hline With ESP & $1.0-4.2$ & -- & -- \\
\hline With cyclone/ESP & -- & $0.4-0.6$ & -- \\
\hline \multicolumn{4}{|l|}{ Overfeed stoker } \\
\hline Uncontrolled & $0.01-2.1$ & -- & -- \\
\hline Dust collector & $0.4-1.2$ & - & $\ldots$ \\
\hline
\end{tabular}

a Dash indicates data not available.

b Electrostatic precipitator.

Source: Ref. 9. 
The data in Table 4 show considerable variation in mercury emissions from large coal-fired boilers. No significant differences in mercury emissions exist between different boiler types or different combustion sectors. However, the available test data indicate that for combustion systems equipped with flue-gas-cleaning devices, significant reductions of mercury emissions were realized. (The effect of flue-gas-cleaning devices on reduction of mercury emissions is discussed in Section 4.)

The effect of combustion modifications for controlling $\mathrm{NO}_{\mathrm{x}}$ on the emissions of trace elements from large coal-fired boilers has also been studied. ${ }^{20-24}$ In tests of a tangentially fired utility boiler equipped with an electrostatic precipitator (ESP) for particulate control, the mercury emissions under low-NO combustion conditions were about $100 \%$ greater than the baseline mercury emissions level. ${ }^{20}$ It was pointed out, however, that this large variation was still within the potential uncertainty normally associated with the level-1 environmental assessment (EA) protocol employed in the tests. The level-1 EA protocol is described in Ref. 2.

\subsection{FLUIDIZED-BED COMBUSTORS}

Fluidized-bed combustors have received increased attention during the past decade, and they are expected to be more commonly used in the future. This type of combustor operates at a temperature $\left(800-900^{\circ} \mathrm{C}\right)$ at which the ash does not fuse, and carbon utilization is somewhat lower than with a PC boiler. As a result, the distribution of trace elements in the streams of ash products could be different than that observed from conventional coal combustors.

To date, only a limited number of tests has been conducted on trace-element emissions from small fluidized-bed combustors, mostly with non-U.S. coals. ${ }^{18}$ When compared with emissions from a small stoker-fired combustor (3.8 MWt) burning the same coal, vapor-phase mercury emissions from a small atmospheric fluidized-bed combustor (3.5 Mwt) were found to be significantly lower $\left(0.3-0.6\right.$ vs. $\left.2.5-5.1 \mu \mathrm{g} / \mathrm{m}^{3}\right)$. However, additional comparable data from large-scale units are needed to substantiate this preliminary observation and to quantify the distribution of mercury in the various process outlet streams. 


\section{INFLUENCE OF FLUE-GAS-CLEANING DEVICES ON MERCURY EMISSIONS}

There are no reports of any measures taken at coal-fired boilers specifically to control mercury emissions, even though some processes have been suggested for the control of mercury emissions from municipal- and hazardous-waste incinerators. However, such particulate-collection devices as ESPs and fabric filters have been widely used for capturing fly-ash particles from coal-fired plants, and scrubbing systems have been used for controlling sulfur dioxide $\left(\mathrm{SO}_{2}\right)$ emissions from large boilers burning high- or medium-sulfur coals. These devices are known to achieve a substantial reduction of low-volatility trace elements that are mostly associated with the fly-ash particles. Because a portion of the mercury present in the flue gas may be in the condensed phase, the effectiveness of these devices in reducing mercury emissions from large coal-fired boilers is discussed here.

\subsection{PARTICULATE-COLLECTION DEVICES}

Particulate-matter controls for coal-fired boilers are extensively discussed in an Argonne report ${ }^{24}$ and in the proceedings of the Particulate Control Symposiums cosponsored by EPA and the Electric Power Research Institute (EPRI). ${ }^{25}$ There are basically four types of devices: ESPs, fabric filters (or baghouses), wet scrubbers, and mechanical collectors (e.g., cyclones). Properly designed ESPs can achieve overall removal efficiencies of $99.5 \%$ or greater, but the efficiency varies with particle size. The collection efficiency is considerably lower for respirable particles (smaller than $10 \mu \mathrm{m}$ ) and can be lower than $90 \%$ for particles in the size range of $0.1-1 \mu \mathrm{m}$.

Fabric filters are inherently high-efficiency particulate-matter collectors, even with variable inlet particulate loading in the flue gas. Typical removal efficiencies are usually greater than $99.5 \%$, and overall removal efficiencies of $99.7-99.8 \%$ have been reported. For particles in the size range of $0.1-1 \mu \mathrm{m}$, the efficiency can be $97-99 \%$.

Of the various types of wet scrubbers, the venturi and moving-bed scrubbers are high-efficiency devices widely used in coal-fired power plants. The efficiency of the venturi scrubbers depends on the pressure drop achieved, about $99 \%$ for 2- and 1- $\mu \mathrm{m}$ particles at $5.5 \mathrm{kPa}$ (22 in. of water) and $15 \mathrm{Kpa}$ (60 in. of water), respectively. The moving-bed wet scrubbers also can achieve a removal efficiency of $99 \%$ for particles greater than $2 \mu \mathrm{m}$. For smaller particles $(0.1-1 \mu \mathrm{m})$, the collection efficiency of wet scrubbers drops rapidly to less than $50 \%$.

Cyclones are the most widely used mechanical collectors, but they have a low overall efficiency: for large particles, less than $90 \%$ for one cyclone and less than $95 \%$ for two cyclones in series. For small respirable particles (less than $5 \mu \mathrm{m}$ ), the efficiency can be as low as 60\%. Hence, this type of particulate-matter control is often used (1) as a means of reducing the overall particulate loading into a more efficient collector or (2) as the only collector in less-turbulent combustors, such as chain-grate stokers. Limited information on 
the removal of trace elements by these devices indicates that the removal efficiency for mercury is nil.

The number of paired data points (inlet and outlet) for mercury emissions from coalfired boilers with any given control device in the United States is limited or nonexistent. Calculated removal efficiencies from the data reported in Refs. 26-47 are aggregated into utility and industrial boiler groups for each control device and are summarized in Table 5. Most of the available data are from boilers equipped with cold ESPs. Also included in the table are results from the EPRI's PISCES (power-plant integrated systems: chemical emissions study) database for power-plant emissions. ${ }^{48}$ In some of the studies, deficits in the mass balance for mercury were encountered; therefore, the values given in Table 5 can only be considered tentative.

With cold ESPs, the calculated efficiencies are $22-91 \%$ for utility boilers and $40-91 \%$ for spreader stokers equipped with a mechanical collector and an ESP in series. In comparison, the PISCES database indicates mercury removal efficiencies of $20-90 \%$ for a cold ESP. These numbers, however, are much higher than the $10-50 \%$ presented in an International Energy Agency (IEA) report by Smith. ${ }^{18}$ Given that ESPs are not known to be efficient in capturing vapors and that a significant portion of the mercury in flue gas is in the vapor form or condensed on fine fly-ash particles, the high-end numbers probably resulted from deficiencies in the sampling and analytical techniques employed. Additional recent unpublished results (from one Japanese coal-fired power plant and one 450-MW power plant in Florida) cited in Ref. 48 also indicate a mercury retention efficiency by the ESP of 33-40\%. In addition, tests from boilters equipped with hot ESPs indicated essentially no mercury removal. $^{31,48}$

No information has been obtained from the open literature on the mercury emissions from U.S. coal-fired boilers equipped with fabric filters for particulate control, and only two data points have been found for units equipped with high-efficiency scrubbers, showing a removal efficiency of about $70 \%$ but with a poor mass balance. The PISCES database (three data points), however, indicates mercury removal efficiencies of $85-90 \%$ with fabric filters. In comparison, the mercury removal efficiencies with fabric filters were reported by $\mathrm{Smith}^{18}$ to be about $50 \%$ (with one case of $90 \%$ ), somewhat lower than the PISCES results. Because of the build-up of filter cake, under some conditions fabric filters probably would provide greater removal of mercury than would ESPs. Additional data, however, are needed to verify this supposition.

\subsection{FLUE-GAS DESULFURIZATION SYSTEMS}

Two types of flue-gas-desulfurization (FGD) systems generally have been used for large coal-fired boilers: wet FGD and dry (spray dryer; SD) FGD systems. The former is typically placed downstream of a particulate-collection device, and it can be used for coals having a range of sulfur contents. Some of the older wet FGD units might also have been designed for simultaneously controlling particulates. In comparison, the spray-drying 
TABLE 5 Summary of Mercury Removal Efficiencies from Coal-Fired Boiler Emissions

\begin{tabular}{lc}
\hline Particulate Control Device & Removal Efficiency (\%) \\
\hline Utility boiler & \\
$\quad$ Cold ESP & $22-91\left(20-90^{\mathrm{a}}\right)$ \\
Hot ESP & 0 \\
Fabric filter & $-\mathbf{b}^{\mathrm{b}}\left(85-90^{\mathrm{a}}\right)$ \\
$\quad$ Scrubber & 70 \\
& \\
Industrial boiler & \\
$\quad$ Cyclone/multiclone & $0-40$ \\
$\quad$ ESP & $40-90$ \\
$\quad$ Fabric filter & -- \\
$\quad$ Scrubber & -- \\
\hline \multicolumn{2}{l}{ From PISCES database (Ref. 48). } \\
bash indicates no data available.
\end{tabular}

reaction chamber in the dry FGD system is located upstream of the particulate-collection device; to date, dry FGD systems have been mainly used with coals having low to medium sulfur contents. Available information in the open literature on the effectiveness of these systems for the reduction of mercury emissions from coal-fired boilers is summarized and discussed in this section.

With wet FGD systems, the removal efficiencies for mercury range from $30 \%$ to as high as $95 \%{ }^{27,49}$ Both the PISCES database and the report by Smith indicate wide variations (10-90\%) in mercury removal efficiency with wet FGD systems. The characteristic features of different types of scrubber designs may contribute to this wide range of efficiencies, but very limited information on the designs and operating conditions has been reported. It is possible that certain types of wet scrubber systems (such as the packed-bed design that was used in some of the early wet FGD systems) may be more effective for mercury removal.

Very limited information is in the open literature on the mercury removal efficiencies of spray-drying scrubbing systems used with coal-fired boilers. For an Austrian power plant equipped with an SD/ESP system that attained $90 \% \mathrm{SO}_{2}$ removal (640 ppm at inlet) with a $36^{\circ} \mathrm{F}$ approach temperature (the difference between the gas temperature and its saturation temperature), mercury was reportedly reduced from 2.74 to $0.32 \mu \mathrm{g}$ per normal cubic meter $\left(\mathrm{Nm}^{3}\right)$ at the exit of the ESP. ${ }^{50}$ In addition, Niro Atomizer, Inc., the original developer of the spray-drying scrubbing system, is currently conducting tests on coal-fired boilers in the United States to determine the mercury removal efficiency. ${ }^{50}$

A significant amount of data on the removal efficiencies of mercury from municipaland hazardous-waste incinerators has been reported. ${ }^{51-57}$ The combination of a lime-based 
spray dryer and fabric filter (SD/FF), which was installed primarily for control of hydrogen chloride and particulates, has provided good mercury removal efficiencies of 75-99\% as long as the flue-gas temperature at the spray-drying chamber outlet is below $150^{\circ} \mathrm{C}$. Results from the evaluation of two pilot-scale SD/FF units indicated essentially no mercury removal when the flue-gas temperature at the SD outlet was higher than $200^{\circ} \mathrm{C}$, and mercury removal efficiencies of $35-45 \%$ were attained with an SD/ESP combination for a flue-gas temperature at the SD outlet of about $140^{\circ} \mathrm{C}$. These observations strongly suggest that a significant amount of mercury in the flue gas from coal-combustion systems would be captured by an $\mathrm{SD} / \mathrm{FF}$ system, because the flue-gas temperature at the $\mathrm{SD}$ outlet is normally below $75^{\circ} \mathrm{C}$ for coal-combustion systems.

However, the typical mercury emissions from waste incinerators are much higher than those encountered in coal-fired boilers $\left(500-1000 \mu \mathrm{g} / \mathrm{Nm}^{3}\right.$ vs. $\left.5-100 \mu \mathrm{g} / \mathrm{Nm}^{3}\right){ }^{50-56}$ Preliminary observations suggest that the presence of a high level of hydrogen chloride in the flue gas from waste incineration systems may result in a greater proportion of the mercury appearing in the form of mercury chloride, which has a higher melting point than mercury and condenses sooner than the pure mercury vapor. Hence, mercury removal efficiencies with the SD/FF system on coal-fired boilers are expected to be no better than those achieved on waste incinerators. 


\section{NEW PROCESSES FOR CONTROL OF MERCURY EMISSIONS}

Several processes have been investigated for the reduction of mercury emissions in flue-gas streams. These include the addition of activated carbon into the flue-gas duct upstream or downstream of the SD chamber (but before the particulate-collection device) in an SD/FF system; $; 0,56,57,58$ a wet scrubbing system with a polysulfide solution and other chemical additives; ${ }^{48,59}$ and a low-temperature plasma process being developed in Japan. ${ }^{60,61}$ In addition, conventional dry carbon adsorption has been applied for mercury control in Europe, ${ }^{48,50,57}$ and another dry sorption process using lignite-derived coke for the reduction of oxides of nitrogen $\left(\mathrm{NO}_{\mathrm{x}}\right)$ also removed essentially all mercury in pilot-scale tests. ${ }^{62}$ These processes are discussed in the following sections.

\subsection{IMPROVED SPRAY-DRYING SCRUBBING SYSTEM}

The spray-drying scrubbing system has been successfully applied to waste incineration systems for controlling (mainly) hydrogen chloride and to coal-fired boilers for controlling $\mathrm{SO}_{2}$ (Section 4.2). Since typical mercury emissions in the flue gases from municipal solid waste (MSW) incinerators are about an order of magnitude higher than those from coal-combustion systems, concern has been raised about reducing mercury emissions from MSW systems. In response to this concern, the standard lime-based spray-drying scrubber system has been improved by using chemical additives to make it capable of removing mercury or other gaseous pollutants from combustion flue gas. Niro Atomizer, Inc., has been granted a European patent for this improved SD/FF process and has applied for a U.S. patent as well. ${ }^{56}$ The process is being used commercially to enhance mercury removal at one incinerator in Zurich.

In this improved version of the spray-drying scrubbing system, a dry activatedcarbon powder is injected into the flue-gas duct either upstream of the spray-dryer chamber or between the spray dryer and the particulate collector. The amount of carbon added during pilot-plant and commercial-plant tests was reported to be $30-80 \mathrm{mg} / \mathrm{Nm}^{3}$ (approximately 0.01 $0.03 \mathrm{~g}$ per actual cubic foot [ACF]). Typical results from the tests are presented in Table 6. In all tests, injection of the carbon resulted in substantial increases in mercury removal. This result was especially notable when an ESP was used as the particulate-collection device and when the spray-dryer absorber (SDA) units were operated at high outlet temperatures $\left(285^{\circ} \mathrm{F}\right)$. With a baghouse as the particulate-matter collector, the mercury removal efficiency increased from $69 \%$ to $91 \%$ even as the SDA outlet temperature was increased from $265^{\circ} \mathrm{F}$ to $285^{\circ} \mathrm{F}$. Using an ESP, the mercury removal efficiency could be increased from $27 \%$ to $78 \%$ at $285^{\circ} \mathrm{F}$ and from $66 \%$ to $86 \%$ at $230^{\circ} \mathrm{F}$. The mechanism behind this increase in removal efficiency was not explained, but it is probably due to physical adsorption of the mercury vapor onto the carbon particles. In addition, the injection of the activated carbon powder also resulted in substantial improvements on dioxin/furan removal and $\mathrm{NO}_{\mathrm{x}}$ removal. ${ }^{56}$ 
TABLE 6 Mercury Removal in Tests with SDA Systems

\begin{tabular}{|c|c|c|c|c|c|c|c|}
\hline & \multicolumn{3}{|c|}{$\begin{array}{l}\text { SDA-Baghouse } \\
\text { Pilot Plant }\end{array}$} & \multicolumn{4}{|c|}{$\begin{array}{c}\text { SDA/ESP } \\
\text { Full-Scale Incinerator }\end{array}$} \\
\hline Outlet temperature $\left({ }^{\circ} \mathbf{F}\right)$ & 230 & 265 & 285 & 230 & 230 & 285 & 285 \\
\hline Additive & Yes & No & Yes & Yes & No & Yes & No \\
\hline $\begin{array}{l}\text { Mercury }\left(\mu \mathrm{g} / \mathrm{Nm}^{3}\right) \\
\text { Inlet } \\
\text { Outlet }\end{array}$ & $\begin{array}{r}350 \\
18\end{array}$ & $\begin{array}{r}287 \\
89\end{array}$ & $\begin{array}{r}413 \\
38\end{array}$ & $\begin{array}{r}486 \\
68\end{array}$ & $\begin{array}{l}411 \\
141\end{array}$ & $\begin{array}{r}395 \\
85\end{array}$ & $\begin{array}{l}537 \\
390\end{array}$ \\
\hline Removal efficiency (\%) & 95 & 69 & 91 & 86 & 66 & 78 & 27 \\
\hline
\end{tabular}

Source: Refs. 50 and 56.

\subsection{POLYSULFIDE WET SCRUBBING PROCESS}

A wet scrubbing process using a polysulfide solution is being investigated at the Mobil Research and Development Corporation for reduction of mercury content in natural gas. ${ }^{61}$ In this scheme, the mercury-containing gas comes into cuntact with an aqueous polysulfide solution in a packed tower. The mercury is removed from the gas by reaction with the polysulfide to form insoluble mercury sulfide. In order to accelerate both the masstransfer and chemical reaction rates, the gas flows over high-surface-area packings wetted with a thin film of the solution. Stainless-steel Propack Cannon ${ }^{\mathrm{TM}}$ packing was used in the laburatory experiments.

The results from the laboratory-scale experiments indicated that the mercury/ polysulfide reaction is mass-transfer-limited in gas feeds having a high mercury content and becomes thermodynamically limited when the mercury content of the feed gas is low. In tests with gas containing a low concentration of mercury, the residual mercury in tine gas could be reduced from about $0.1 \mathrm{ppb}$ to below $0.01 \mathrm{ppb}$, a reduction of greater than $90 \%$, with a solution containing 3-ppm polysulfide salt. For this high level of mercury removal, the gas superficial velocity could be as high as $13 \mathrm{~cm} / \mathrm{s}$, and the liquid velocity was not critical because the packings served as a reservoir for polysulfides. In addition to promoting gas/liquid contact, the stainless-steel packing was found to adsorb and concentrate polysulfides on the surface to racilitate reaction between mercury and polysulfides, as well as to directly adsorb the mercury. However, the capacity of the latter mechanism was limited, and breakthrough occurred within 30 days.

No data have been reported on the effectiveness of this process for treating gas containing 1-10 ppb mercury, which is more representative of the typical mercury concentrations encountered in flue gases from coal-fired boilers. Also, the effect of the presence of oxygen in the flue gas on the performance of this process is not known, and the 
presence of mercuric sulfide $(\mathrm{HgS})$ in the scrubbing wastewater may require additional treatment.

In a related process being investigated in Japan, mercury removal efficiencies of 95-100\% were reported for the flue gas from a municipal waste incinerator using a wet limebased flue-gas-cleaning system. ${ }^{48}$ in this system, an oxidizing agent (sodium hypochlorite, $\mathrm{NaOCl}$ ) was added to the scrubber to solubilize the mercury, which later was removed from the scrubbing wastewater through a complicated reduction, volatilization, condensation, and separation process. No detailed information was provided; however, the process is suspected to be costly.

\subsection{LOW-TEMPERATURE PLASMA PROCESS}

A nonequilibrium, pulse-corona-induced, low-temperature plasma-chemical process (PPCP) was developed several years ago by a group of Japanese researchers for effective reduction of $\mathrm{NO}_{\mathrm{x}}$ and $\mathrm{SO}_{2}$ in flue gases from combustion systems, and it has recently been applied to the control of mercury vapor in flue gases from municipal waste incinerators. 59,60 Unlike ordinary plasma-chemical processes performed in a low-pressure gas atmosphere, PPCP can be operated under ordinary pressure, producing large numbers of such oxidizing radicals as $\cdot \mathrm{O} \cdot \mathrm{OH} \cdot \mathrm{O}_{3}$, etc. In this process, a very narrow pulse is used in combination with a corona electrode system to accelerate only the electrons and not the ions. In this case, the mechanism for minimizing the ion/molecule temperature rise caused by electron. bombardment is through a very low duty ratio of the pulse (ratio of the pulse duration time to the total pulse repetition period), which allows sufficient cooling time for ions and molecules that had been partially heated by electron collisions.

Typical results from laboratory experiments on the removal efficiency of mercury vapor from the flue gas in an incineration system are shown in Figure 1. The removal efficiency increases with peak pulse voltage and residence time but decreases with the operating gas temperature. With a reactor residence time of $2 \mathrm{~s}$, removal efficiencies of greater than $95 \%$ were achieved at a peak pulse voltage of about $50 \mathrm{kV}$. No information concerning the state of the mercury after this plasma treatment was reported. It is expected that the mercury vapor is converted into a condensed phase of fine particles, which still needs to be captured by a high-efficiency particulate-matter-collection device. Future plans for the scale-up of this process are unknown.

\subsection{DRY ADSORPTION PROCESS}

The dry adsorption process has been developed mainly for the removal of mercury in flue gases from MSW incinerators. In Europe, carbon filters are being tried, with encouraging results, and a pilot-scale moving-bed carbon filter is under development for mercury removal. ${ }^{59}$ Another pilot-scale unit was evaluated on an MSW incineration plant that used lignite coke as the sorbent for removal of $\mathrm{NO}_{\mathrm{x}}$ from flue gas after it passed through 


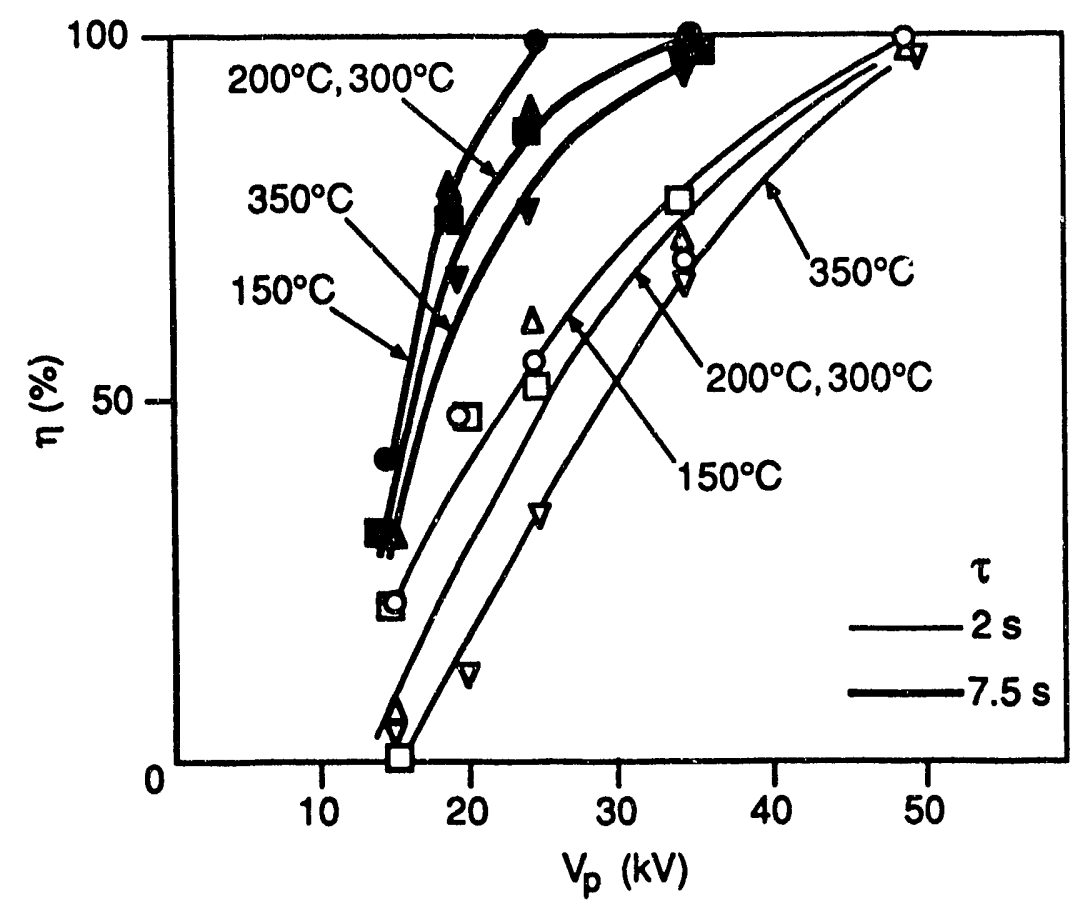

FIGURE 1 Efficiency of Mercu $>\mathrm{g}$ Vapor Removal from Incinerator Flue Gas by the Low-Temperature Plasma Process (Source: Ref. 59)

an FGD system, while simultaneously being cooled to $80-100^{\circ} \mathrm{C}$. In addition to high $\mathrm{NO}_{\mathrm{x}}$ reduction with ammonia, virtually all mercury in the flue gas entering the adsorption bed $\left(100-1000 \mu \mathrm{g} / \mathrm{m}^{3}\right)$ was removed. ${ }^{62}$ Since typical concentrations of mercury in the flue gas from U.S. coal-fired boilers are about 10 times or more lower than the mercury concentrations in the flue gas from MSW incinerators, this process probably will be less effective when applied to coal-fired boilers.

Another adsorption approach uses a selenium filter, forming mercuric selenide (HgSe). ${ }^{57}$ Very little information, however, has become available. 


\section{CONCLUSIONS AND RECOMMENDATIONS}

\subsection{CONCLUSIONS}

Available information on the mercury concentrations in U.S. coals and on mercury emissions during combustion suffers from inaccuracies and inconsistencies in the sampling and analytical procedures used and from a lack of information on the coal variables and plant operating conditions during the tests. It is therefore difficult to make comparisons between work by different researchers on the effectiveness of different types of particulate-collection and flue-gas-cleaning systems for mercury emissions. Some tentative conclusions follow:

1. Mercury concentrations in U.S. coals show differences by region and by coal rank. The exact forms of mercury in the coals, however, are less well-known. If, as reported in some analyses, mercury is principally associated with the mineral constituents in coals, then a large portion of the morcury could be removed by physical coalcleaning methods.

2. During combustion, greater than $95 \%$ of the mercury in coal is vaporized into the flue gas. Some of the vaporous mercury probably is condensed during flue-gas cooling through the heat-transfer devices. The degree of condensation depends strongly on the mercury concentration in the flue gas and the operating conditions of the heattransfer devices. Enrichment of mercury on finer fly-ash particles has been observed, but the forms of the mercury in the flue gas and on the fly-ash particles are not well-known.

3. Compared with data on other trace elements, few data are available on emissions of vapor-phase trace elements, including mercury, from coal-fired boilers. This information is needed in assessing the potential effect of emissions of mercury on the environment.

4. Of the information available on mercury emissions from coal-fired boilers, a major portion is associated with plants equipped with cold ESPs for the control of particulate matter. The effectiveness of ESPs for control of mercury emissions was found to be $20-50 \%$.

5. Very little information is available on the effectiveness of fabric filters and wet scrubbers for control of mercury emissions from coal-fired boilers. These devices, however, probably would show removal efficiencies for mercury equal to or better than those achieved by ESPs.

6. Limited data on wet FGD systems indicate that these devices are effective in controlling mercury vapor emissions. A combination of 
ESP and wet FGD systems can achieve removal efficiencies up to $80 \%$ for the mercury in the flue gas.

7. The data from an Austrian power plant equipped with an SD/ESP combination achieving $90 \%$ removal of $\mathrm{SO}_{2}$ indicate a high removal efficiency (about $88 \%$ ) for mercury. Additional data are needed to substantiate this high removal efficiency.

8. The removal efficiency of spray-dryer-based FGD systems for mercury can be further improved by the injection of activated-carbon powder into the flue-gas duct. This technique, however, has only been demonstrated on flue gases from waste incinerators.

9. Three other teuhnologies - polysulfide wet scrubbing, lowtemperature plasma, and dry adsorption - have been reported in the literature for good control of mercury in incinerator flue gas or in methane gas, but they have not been evaluated on coal-combustion flue gas.

\subsection{RECOMMENDATIONS}

1. Investigate the effectiveness of physical coal-cleaning methods for the removal of constituent mercury from coal.

2. Conduct experiments, as part of the U.S. Department of Energy's studies on air toxics from coal-fired plants, to characterize mercury emissions (including the various forms of mercury) from plants equipped with fabric filters, wet FGD systems, and spray-dryer FGD systems.

3. Monitor closely the results of the studies being conducted by EPRI on air toxics from coal-fired power plants.

4. Develop techniques for improved removal of mercury from flue gases to $\in$ nsure that control technologies are available when needed. 


\section{REFERENCES}

1. U.S. Department of Energy, 1991, Summary of the Clean Air Act Amendments of 1990 and a Preliminary Analysis of Their Implications for DOE, unpublished report, Office of Environmental Guidance, Air/Water/Radiation Division, March.

2. ENSR Consulting and Engineering, 1988, Air Quality Handbook, 10th ed., Acton, Mass., June.

3. Schroeder, W.H., et al., 1987, "Toxic Trace Elements Associated with Airborne Particulate Matter: a Review," Journal of the Air Pollution Control Association, 37(11):1267-1285, Nov.

4. van Hook, R.I., and W.D. Shults, Eds., 1977, Effects of Trace Contaminants from Coal Combustion, U.S. Department of Energy Report ERDA-77-64, June.

5. Heit, M., 1987, A Review of Current Information on Some Ecological and Health Related Aspects of the Released Metals into the Environment Associated with the Combustion of Coal, U.S. Department of Energy (ERDA) Report HASL-320, June.

6. Lee, R.E., and D.J. von Lehmden, 1973, "Trace Metal Pollution in the Environment," Journal of the Air Pollution Control Association, 23(10):853-857, Oct.

7. Magee, E.M., et al., 1973, Potential Pollutants in Fossil Fuels, U.S. Environmental Protection Agency Report EPA-R2-73-249, June.

8. Ruch, R.R., et al., 1974, Occurrence and Distribution of Potentially Volatile Trace Elements in Coal: a Final Report, Illinois State Geological Survey Report, Environmental Geology Notes No. 72, Aug.

9. Radian Corporation, 1989, Estimating Air Toxics Emissions from Coal and Oil Combustion Sources, U.S. Environmental Protection Agency Report EPA-450/2-89-001, April.

10. White, D.M., et al., 1984, Correlation of Coal Properties with Environmental Control Technology Needs for Sulfur and Trace Elements, U.S. Environmental Protection Agency Report EPA-600/7-84-066, June.

11. Kuhn, J.K., et al., 1980, Abundance of Trace and Minor Elements in Organic and Mineral Fractions of Coal, U.S. Environmental Protection Agency Report EPA-600/780-003, Jan.

12. E. Raask, 1985, The Mode of Occurrence and Concentration of Trace Elements in Coal, Progress in Energy Combustion Sciences, 11(2):97-117. 
13. Gluskoter, H.J., et al., 1977, Trace Elements in Coal: Occurrence and Distribution, Illinois State Geological Survey Report, Circular 499.

14. Swanson, V.E., et al., 1976, Collection, Chemical Analysis, and Evaluation of Coal Samples in 1975, U.S. Geological Survey Report 76-468.

15. Mezey, E.J., et al., 1976, Fuel Contaminants, Vol I: Chemistry, U.S. Environmental Protection Agency Report EPA-600/2-76-177a, July.

16. Fisher, G.L., et al., 1977, Size-Dependence of the Physical and Chemical Properties of Coal Fly Ash, Preprints of Fuel Chemistry Division, American Chemical Society, 22(4):149-155, May.

17. Davison, R.L., et al., 1974, "Trace Elements in Fly Ash: Dependence of Concentration on Particle Size," Environmental Science and Technology, 8(12):1107-1113, Dec.

18. Smith, I.M., 1987, Trace Elements from Coal Combustion: Emissions, International Energy Agency Coal Research Report IEACR/01, June.

19. Coutant, R.W., et al., 1975, Trace Elements in a Combustion System, Electric Power Research Institute Report EPRI 122-1, Jan.

20. Higginbotham, E.B., et al., 1981, Combustion Modification $\mathrm{NO}_{x}$ Controls for Utility Boilers. Vol. I: Tangential Coal-Fired Unit Field Test, U.S. Environmental Protection Agency Report EPA-600/7-81-124A, July.

21. Sawyer, J.W., et al., 1981, Combustion Modification NO $\mathrm{X}_{x}$ Controls for Utility Boilers. Volume II: Pulverized-Coal Wall-Fired Unit Field Test, U.S. Environmental Protection Agency Report EPA-600/7-81-124B, July.

22. Lim, K.J., et al., 1980, Environmental Assessment of Utility Boiler Combustion Modification $\mathrm{NO}_{x}$ Controls: Volume 1. Technical Results, U.S. Environmental Protection Agency Report EPA-600/7-80-075a, April.

23. Surprenant, N., et al., 1976, Preliminary Emissions Assessment of Conventional Stationary Combustion Systems, Vol. II, U.S. Environmental Protection Agency Report EPA-600/2-76-0466, NTIS Order No. PB 252-175, March.

24. Southern Research Institute, 1977, Environmental Control Implications of Generating Electric Power from Coal, 1977 Technology Status Report, Appendix E: A Review of Technology for Control of Fly Ash Emissions from Coal In Electric Power Generation, Argonne National Laboratory Report ANL/ECT-3, Dec.

25. Electric Power Research Institute, 1990, Proceedings: Eighth Particulate Control Symposium, Electric Power Research Institute Report EPRI GS-7050, Vols. I and II, Nov. 
26. Zielke, R.L., et al,, 1982, Fitld Study to Obtain Trace Element Mass Balances at Konston Steam Plant: Final Report, U.S. Environmental Protection Agency Report EPA-600/7-82-042, May.

27. Scinto, L.L., et al., 1981, Source Test and Evaluation Report: Cane Run Unit No. 6 Louisville Gas and Electric Co. (Final Report Sept. '79-June '81), U.S. Environmental Protection Agency Report EPA-600/7-81-134, Aug.

28. Edwards, L.O., et al., 1980, Trace Metals and Stationary Conventional Combustion Processes: Volume 1. Technical Report, U.S. Environmental Protection Agency Report EPA-600/7-80-155A, Aug.

29. Evers, R., et al., 1980, Field Study to Obtain Trace Element Mass Balances at a CoalFired Utility Boiler, U.S. Environmental Protection Agency Report EPA-600/7-80-171, Oct.

30. Leavitt, C., et al., 1980, Environmental Assessment of a Coal-Fired Controlled Utility Boilers: Finci: Report, U.S. Environmental Protection Agency Report EPA/600-7-80086, April.

31. Mann, R.M., et al., 1978, Trace Elements of Fly Ash: Emissions from Coal-Fired Steam Plants Equipped with Hot-Side and Cold-Side Electrostatic Precipitators for Particulate Control, U.S. Environmental Protection Agency Report EPA/900/4-78/008, Dec.

32. Radian Corporation, 1990, The EPRI PISCES Database System: Bibliography, Draft Report, Radian Corp., Austin, Texas, Feb.

33. Kaakinen, J.W., et al., 1975, "Trace Element Behavior in Coal-Fired Power Plants," Environmental Science and Technology, 9(9):773-779, Sept.

34. Kaakinen, J.W., and R. M. Jordan, 1974, "Determination of a Trace Element Mass Balance for a Coal-Fired Power Plant," Proc. of the First Annual NSF Trace Contaminant Conference, pp. 165-184, W. Fulkerson, et al., eds., CONF 73082, U.S. Atomic Energy Commission, Technical Information Center, Oak Ridge, Tenn.

35. Klein, D.H., et al., 1975, "Pathways of Thirty-Seven Trace Elements through CoalFired Power Plant," Environmental Science and Technology, 9(10):973-979, Oct.

36. Lyon, W.S., 1977, Trace Element Measurements at the Coal-Fired Power Plants, CRC Press, Cleveland, Ohio.

37. Mesich, F.G., et al., 1975, Coal Fired Power Plant Trace Element Study, Vol. I, a Three Station Comparison, U.S. Environmental Protection Agency, Region 8, Report, NTIS Order No. PB-257 293, Sept. 
38. Radian Corporation, 1975, Coal Fired Power Plant Trace Element Study, Vol. II, U.S. Environmental Protection Agency, Region 8, Report, NTIS PB-283 278, Austin, Texas, Sept.

39. Ensor, D.S., et al., 1976, Determination of the Fractional Efficiency, Opacity Characteristics, Engineering and Economic Aspects of a Fabric Filter Operating on a Utility Boiler, Electric Power Research Institute Report EPRI FP-297, Nov.

40. Yeh, J.T., et al, 1976, Removal of Toxic Trace Elements from Coal Combustion Effluent Gas, Pittsburgh Energy Technology Center Report PERC/RI-76/5, Sept.

41. Burlingame, J.O., et al., 1981, Field Tests of Industrial Coal Stoker Fired Boilers for Inorganic Trace Element and Polynuclear Aromatic Hydrocarbon Emissions, U.S. Environmental Protection Agency Report EPA-600/7-81-167, Oct.

42. Surprenant, N.F., et al., 1981, Emissions Assessment of Conventional Stationary Combustion Systems: Volume V: Industrial Combustion Sources, U.S. Environmental Protection Agency Report EPA-600/7-81-003C.

43. McCurley, W.R., et al., 1979, Source Assessment: Dry Bottom Industrial Boilers Firing Pulverized Bituminous Coal, U.S. Environmental Protection Agency Report EPA-600/279-019E, June.

44. Leavitt, C., et al., 1978, Environmental Assessment of Coal- and Oil-Firing in Controlled Industrial Boilers, U.S. Environmental Protection Agency Report EPA600/7-78-164A, Aug.

45. Leavitt, C., et al., 1978, Environmental Assessment of Coal- and Oil-Firing in Controlled Industrial Boilers, U.S. Environmental Protection Agency Report, EPA600/7-78-164B, Aug.

46. Leavitt, C., et al., 1978, Environmental Assessment of Coal- and Oil-Firing in Controlled Industrial Boilers, U.S. Environmental Protection Agency Report, EPA600/7-78-164C, Aug.

47. Cato, G.A., 1976, Field Testin૬: Trace Element and Organic Emissions from Industrial Boilers, U.S. Environmental Protection Agency Report, EPA/600/2-76/006B, Oct.

48. Chow, W., et al., 1991, "Managing Air Toxics under the New Clean Air Act Amendments," Power Engineering, 95(1):30-34, Jan.

49. Smith, E.O., et al., 1982, Full-Scale Scrubber Characterization of Conesville Unit 5, Electric Power Research Institute Report EPRI CS/2525, Aug.

50. Zohouralsen, O., and O. Christiansen, 1991, "Activated-Carbon Addition Process for Control of Mercury and/or Dioxin Emissions," presented at the 1991 Dry FGD User Seminar, King of Prussia, Penn., June 17-20. 
51. Hartman, R.M., "Particulate Emissions from Prepared Fuel (RDF) Municipal Waste Incinerators," Proceedings: Eighth Particulate Control Symposium, Vol. 2: Baghouse and Particulate Control for New Applications, pp. 37-1 to 37-13, Electric Power Research Institute Report EPRI GS-7050, Vol. 2.

52. Damle, A.S., et al., 1990, "Condensible Emissions from Municipal Waste Incinerators," Proceedings: Eighth Particulate Control Symposium, Volume 2: Baghouse and Particulate Control for New Applications, pp 38-1 to 38-13, Electric Power Research Institute Report EPRI GS-7050, Vol. 2, Nov.

53. Tseng, S.C., et al., 1990, "Mercury Emissions Controls for Municipal Waste Incinerators," presented at the American Institute of Chemical Engineers Summer National Meeting, San Diego, Calif., Aug. 20-23.

54. Klicius, R., et al., 1988, "The National Incinerator Testing and Evaluation Program: Air Pollution Control Technology Assessment Results," Hazardous Waste \& Hazardous Materials, 5(1):53-64, Jan.

55. Environment Canada, 1986, The National Incinerator Testing and Evaluation Program: Air Pollution Control Technology, EPS 3/UP/2, Sept.

56. Donnelly, J.R., and K.S. Felsvang, 1989, Joy/Niro SDA MSW Gas Cleaning System: New Developments, presented at the Air \& Waste Management Association Annual Meeting, Anaheim, Calif., June 25-30.

57. Livengood, C.D., 1991, Argonne National Laboratory, unpublished information, July.

58. Brna, T.G., and J.D. Kilgroe, 1990, "The Impact of Particulate Emissions Control on the Control of Other MWC Air Emissions," Journal of the Air \& Waste Management Association, 40(9):1324-1330, Sept.

59. Masuda, S., and J. Wang, 1990, "DeSO $x$ and $\mathrm{DeNO}_{\mathrm{x}}$ by PPCP and SPCP," Proceedings: Eighth Particulate Control Symposium, Vol. 1: Electrostatic Precipitators, pp. 8-1 to 8-9, Electric Power Research Institute Report EPRI GS-7050, Vol. 1, Nov.

60. Masuda, S., et al., 1987, "Pulse Corona Induced Plasma Chemical Process for DeNOx, DeSOx and Mercury Vapor Control," Proceedings of Third International Conference on Electrostatic Precipitation, pp. 667-676, Oct.

61. Yan, T.Y., "Reaction of Trace Mercury in Natural Gas with Dilute Polysulfide Solutions in a Packed Column," presented at the American Institute of Chemical Engineers Spring National Meeting, Houston, Texas, April 7-11.

62. Marnet, C., et al., 1988, "Use of Lignite Coke for Reduction of $\mathrm{NO}_{\mathbf{x}}$ after Flue Gas Desulfurization," presented at the Fourth Symposium on Integrated Environmental Control, Washington, D.C., March 2-4. 
APPENDIX:

REVIEW OF SAMPLING AND ANALYSIS METHODS FOR EMISSIONS OF MERCURY AND ITS COMPOUNDS FROM

COAL-BURNING FACILITIES 


\title{
APPENDIX:
}

\section{REVIEW OF SAMPLING AND ANALYSIS METHODS FOR EMISSIONS OF MERCURY AND ITS COMPOUNDS FROM COAL-BURNING FACILITIES}

\author{
by
}

\author{
S. Zaromb
}

\section{A.1 INTRODUCTION}

The 1990 Amendments to the Clean Air Act aim to reduce emissions (both gaseous and particulate) of 189 substances called "air toxics."1,2 Among these substances are heavy metals (including mercury) that are present in trace quantities in fossil fuels and are components of the exhaust emissions from power-plant boilers and other combustion processes. $^{2,3}$ Mercury is of special concern because it ends up in soil and water and moves up the food chain, ultimately accumulating in the tissues of fish and fish-eating predators. ${ }^{2}$ The most toxic forms of mercury that accumulate in fish and animal tissue are dimethyl and monomethyl mercury compounds. ${ }^{2,4}$

Man-made sources account for about $30-55 \%$ of global atmospheric mercury emissions, of which about half is attributed to fossil-fuel combustion. ${ }^{2,5}$ Of the mercury that enters coal-fired power plants, without control, more than $90 \%$ is released as vapor into the atmosphere. ${ }^{3,5,6}$ However, the methods used to analyze for mercury in power-plant emissions do not distinguish between elemental mercury and the various mercury compounds. Also, very little is known about interconversions of the various forms of mercury in the atmosphere, in soils, and in water.

The EPA Reference Methods for mercury ${ }^{7}$ were not specifically promulgated for power plant emissions; methods 101 and 102 apply to chlor-alkali plants only. Method 101A, developed for sewage sludge incineration, may also be applicable to other combustion sources. ${ }^{3}$ A variant of this method, using a modified EPA Method 5 sampling train and a different absorbent in two of the impingers, gave results that were statistically similar to those of the original method. ${ }^{3}$ This variant is deemed to be "most desirable" because of its "particulate collection efficiency, ease of operation, availability, and cost." ${ }^{3}$ It also is compatible with the sampling of other trace elements (including lead, beryllium, and arsenic) and analysis for such elements by either inductively coupled argon plasma spectroscopy or atomic absorption spectroscopy. The EPA-approved analytical method for mercury determination is cold-vapor atomic absorption spectroscopy, ${ }^{3,7}$ but other methods have been used. ${ }^{6,8-11}$

The following sections contain a critical review of the existing sampling and analysis methods for the determination of mercury and its compounds in the emissions from coal-burning facilities. This review is followed by suggestions for improvement. 


\section{A.2 OVERVIEW OF EXISTING SAMPLING AND ANALYSIS METHODS FOR MERCURY EMISSIONS FROM COAL-BURNING FACILITIES}

\section{A.2.1 EPA Method 101A}

Particulate and gaseous emissions are withdrawn isokinetically from the source at a rate of less than $1 \mathrm{ft}^{3} / \mathrm{min}(28 \mathrm{~L} / \mathrm{min})$ and are absorbed in acidic potassium permanganate solution ( $4 \% \mathrm{KMnO}_{4}$, wt/vol, in $10 \% \mathrm{H}_{2} \mathrm{SO}_{4}$, vol/vol) contained in three impingers in an EPA Method 5 sampling train ${ }^{12}$ (Figure A.1) for a minimum recommended sampling time of $2 \mathrm{~h}$. The solution collected from three impingers is combined with rinsings from the probe, filter, and filter holder and diluted to a known volume, and it is further diluted, as needed, to bring the sample into the working range of the spectrophotometer. A sample of 1-20 Ml (usually $5 \mathrm{Ml}$ ) of the diluted solution is introduced into an aeration cell (Figure A.2) containing $25 \mathrm{Ml}$ of deionized distilled water, to which are added (a) $5 \mathrm{Ml}$ of the acidic $4 \%$ permanganate solution, (b) $5 \mathrm{Ml}$ of $15 \% \mathrm{HNO}_{3}$, (c) $5 \mathrm{Ml}$ of $5 \% \mathrm{Kmno}_{4}$ (wt/vol), and (d) about $5 \mathrm{Ml}$ of $12 \%$ (wt/vol) hydroxylamine hydrochloride in 1-Ml increments until the solution is colorless (and hence free of permanganate). Then the mercury is reduced to its elemental form by adding $5 \mathrm{Ml}$ of $0.4 \mathrm{M} \mathrm{SnCl}_{2}$ in $1.2 \mathrm{M} \mathrm{Hcl}$ and stirring for $15 \mathrm{~s}$, after which the cell is immediately aerated with nitrogen or mercury-free air (at a flow rate of $1.5 \pm 0.1 \mathrm{~L} / \mathrm{min}$ using the aeration system of Figure A.3) with continued stirring. The atomic absorption of the aerated mercury vapor in the optical cell of Figures A.3 and A.4 is measured with a spectrophotometer containing a hollow-cathode mercury lamp, and the concentration of mercury in the emissions is deduced from the absorption value and other relevant data.

The detailed procedures are far more complex and elaborate than might appear from the preceding summary overview. It is therefore no surprise that modifications of this method have been sought and favored. ${ }^{3,13}$

\section{A.2.2 Proposed Modifications in EPA Method 101A}

The modifications recommended by Osmond et al. ${ }^{13}$ and the Radian Corporation ${ }^{3}$ apply mainly to the sampling apparatus and procedure. A modified EPA Method 5 train comprises five impingers, three of which contain the following absorbing solutions:

- Impingers No. 2 and 3 contain $10 \% \mathrm{H}_{2} \mathrm{O}_{2}$ in either the previously recommended ${ }^{13} 5 \% \mathrm{HNO}_{3}$ or a $0.1 \mathrm{~N} \mathrm{HNO}_{3}$ solution (preferred by Radian). ${ }^{3}$ Either one of these solutions is used for the absorption of all metals of interest.

- Impinger No. 4 contains acidified permanganate solution for the absorption of mercury.

This train operates at a flow rate of about 0.5 standard $\mathrm{ft}^{3} / \mathrm{min}(14 \mathrm{~L} / \mathrm{min})$ over a $4-\mathrm{h}$ sampling period. ${ }^{3}$ 


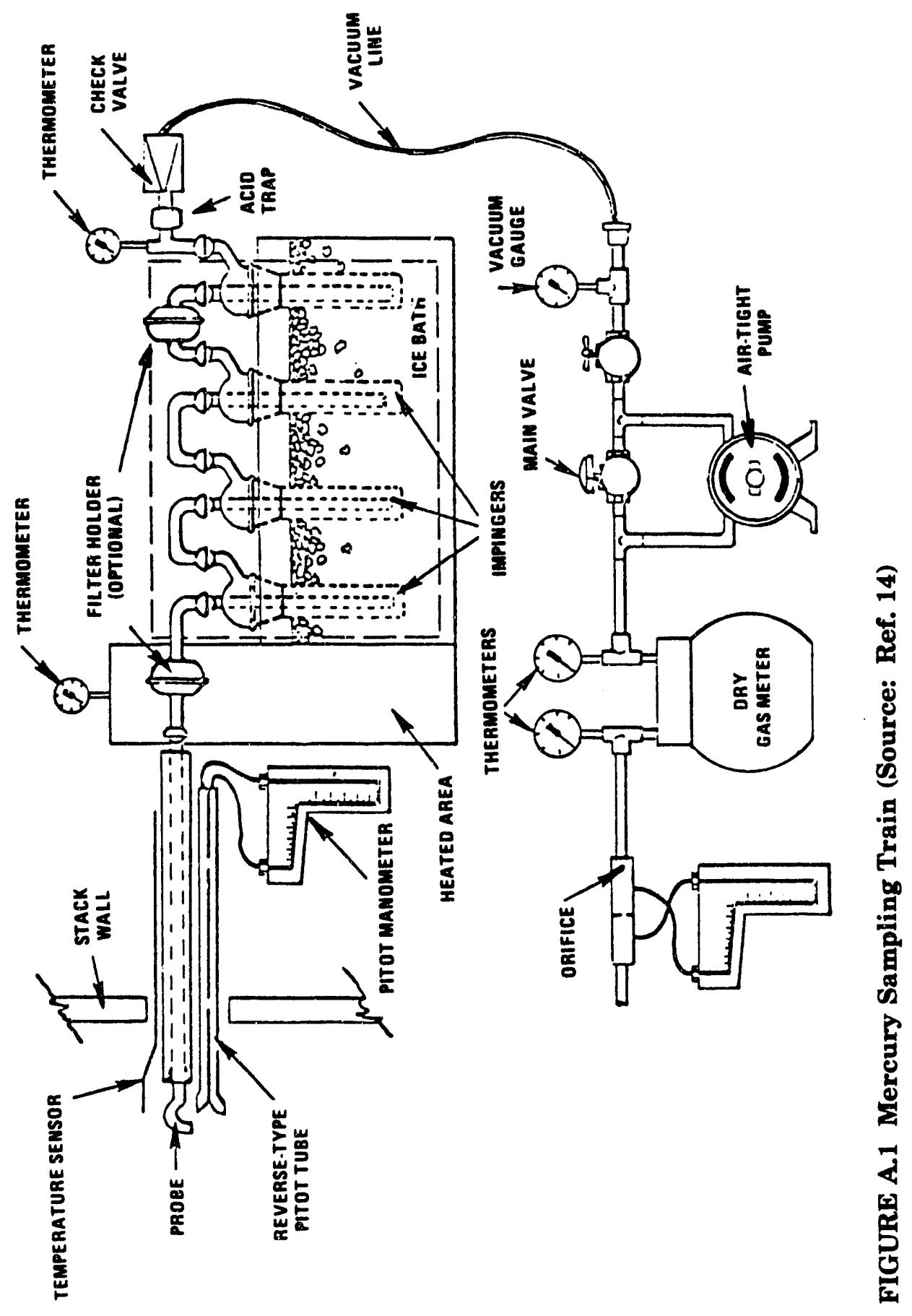




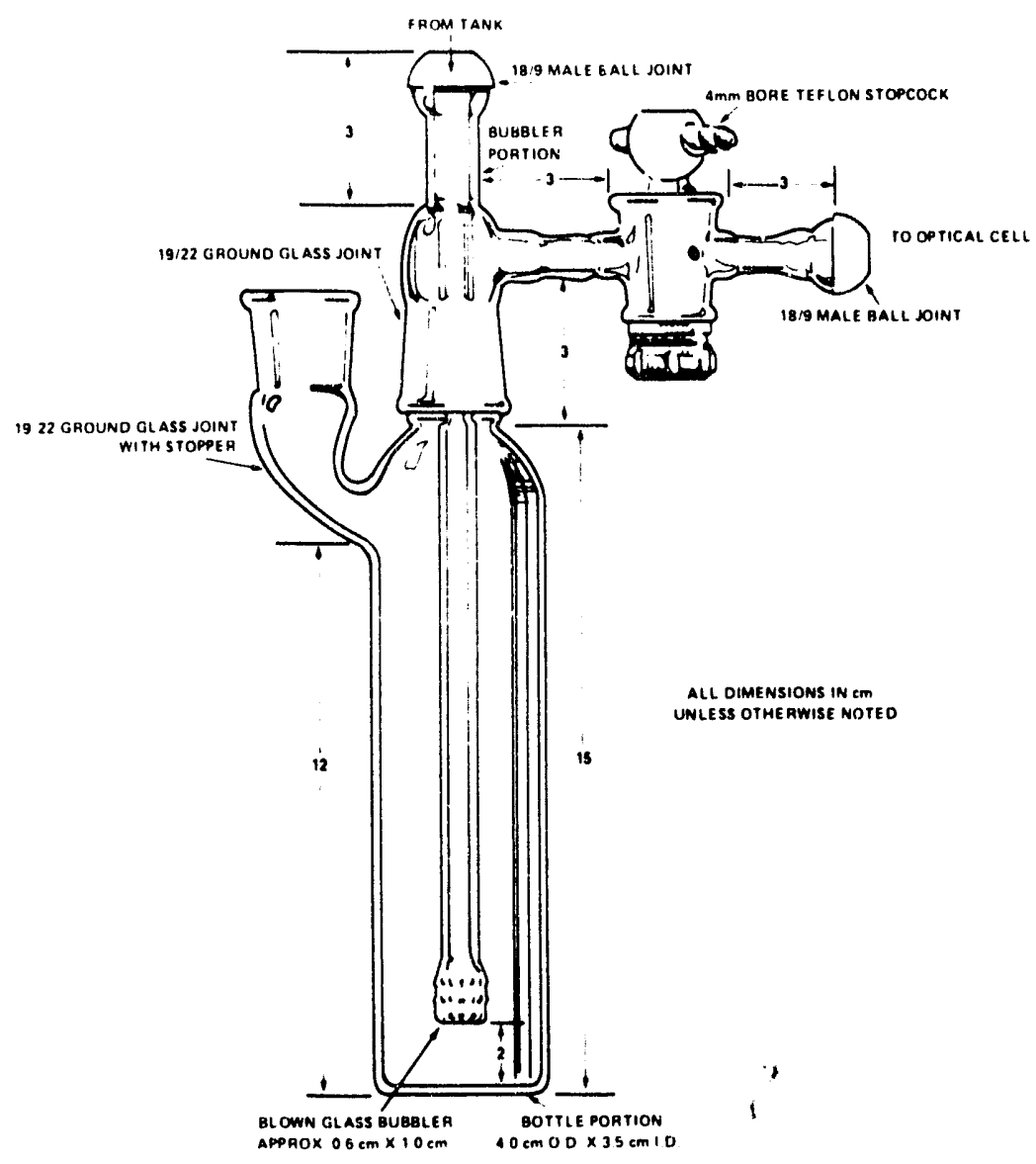

FIGURE A.2 Aeration Cell (Source: Ref. 14)

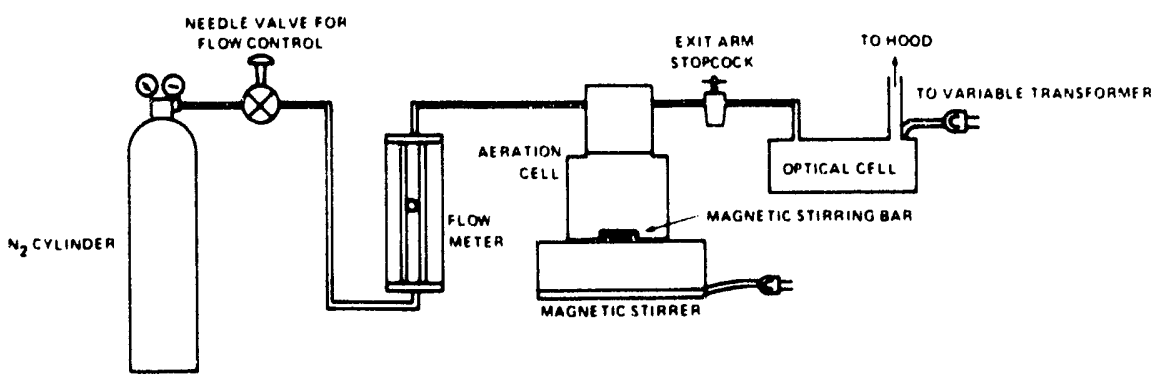

FIGURE A.3 Schematic of Aeration System (Source: Ref. 14) 


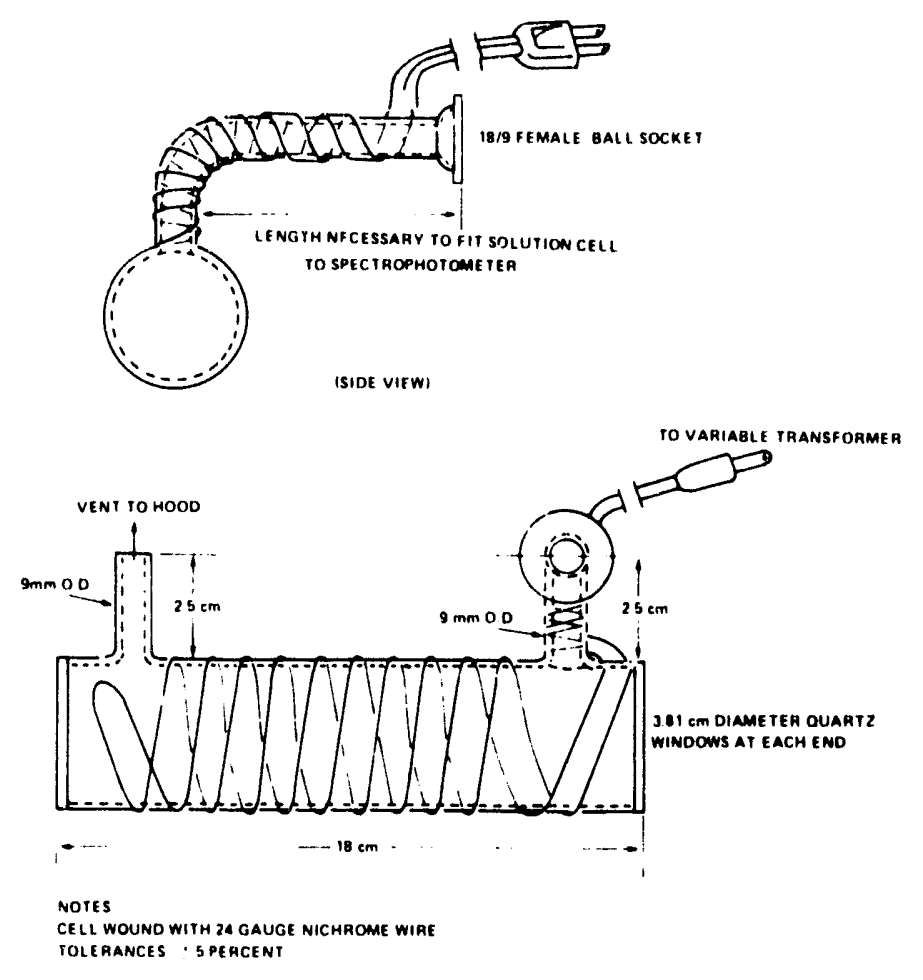

FIGURE A.4 Optical Cell (Source: Ref. 14)

The modified procedure also involves digestion steps with evaporation of the solutions to near dryness using either conventional or microwave heating. ${ }^{3}$ It is not clear from Ref. 3 whether these additional steps are mainly applicable to metals other than mercury or whether they are necessitated by the soot that is generated in coal burning. To clarify this question it is necessary to review Ref. 13, which was not available at the time of writing.

\section{A.3 SHORTCOMINGS OF THE PRESENT METHODS AND AREAS OF POTENTIAL IMPROVEMENT}

Besides being extremely slow (sampling time of $2 \mathrm{~h}$ or more), complex, and elaborate, the EPA Method 101A and its proposed variants ${ }^{3,13}$ do not distinguish between elemental mercury and mercury compounds, especially the highly toxic methyl mercury species. Therefore, the following subsections deal with possible improvements in (1) accelerated sampling and (2) distinguishing among species of the collected mercury.

\section{A.3.1 Accelerated Sampling Methods}

EPA Method 101A and its proposed variants meet the requirement for isokinetic sampling. "The collection of a sample under nonisokinetic conditions results in a 
nonrepresentative particulate sample, the distortion being greatest when a significant fraction of the particles is greater than $5 \mu \mathrm{m}$ in size. ${ }^{.15}$ Such a distortion may cause serious errors when a substantial fraction of the analyte may be carried by the particulates. However, greater than $90 \%$ of the mercury from coal-fired power plants is emitted in the form of vapor. ${ }^{3,5,6}$ Hence, the main objection to nonisckinetic sampling would not apply to the monitoring of mercury emissions.

The source assessment sampling system (SASS) samples stack gases nonisokinetically at a rate of 4 standard $\mathrm{ft}^{3} / \mathrm{min}(112 \mathrm{~L} / \mathrm{min}), 3,16,17$ which is 5-8 times faster than with the isokinetic method. Substitution of the SASS for the Method 5 train would therefore reduce the minimum recommended sampling time from $2 \mathrm{~h}$ to $20 \pm 5 \mathrm{~min}$.

The sampling rate of the SASS appears to be limited to about $4 \mathrm{ft}^{3} / \mathrm{min}\left(0.11 \mathrm{~m}^{3} / \mathrm{min}\right)$ because of its in-line sorbent cartridge(s) and impingers. Substitution of a recently developed high-throughput liquid-absorption sampler ${ }^{18}$ for each of the impingers and sorbent cartridge(s) should permit an increase in sampling rate to about $1 \mathrm{~m}^{3} / \mathrm{min}$. Such a substitution would reduce the minimum required sampling time to about $3 \mathrm{~min}$ or less.

Accelerated sampling and analysis for mercury could lead to the development of automated continuous monitors for coal- or waste-combustion systems.

\section{A.3.2 Differentiation Between Elemental Mercury and Mercury Compounds}

Published methods for differentiating between elemental mercury and mercury compounds fall into two categories: (1) methods using a gas chromatography column, either alone ${ }^{19-21}$ or in conjunction with an adsorbent cartridge, ${ }^{10,22}$ and (2) methods using selective sorbents. ${ }^{9,23-32}$ Selective sorbents could be easily inserted in either the Method 5 or the SASS sampling train, as could an adsorbent cartridge having both interconnections that can be switched from the train to the gas chromatography column and an adjustable heater, so that its temperature can be varied to permit thermal desorption.

A gas chromatography column with a switchable adsorbent cartridge would be more expensive and more complex than a series of sorbent tubes, but it would permit detailed identification of a variety of mercury compounds. In contrast, a set of sorbent tubes would permit distinction between only a few selected compounds or families of compounds, but it could be more readily adapted to the accelerated sampling methods of Section 3.1.

\section{A.4 CONCLUSIONS AND RECOMMENDATIONS}

The EPA Method 101A and its recently proposed variant(s) are so complex, elaborate, and time-consuming that they could only serve for sporadic verifications of compliance with emission standards. Further, they do not provide any information about the forms of mercury being emitted or (especially) about the concentrations of the extremely toxic organomercury compounds (as opposed to the far less toxic elemental mercury). 
Insertion into either the Method 5 or the SASS train of either selective sorbents alone or a nonselective sorbent that is connected to a gas chromatograph would permit differentiation of the forms of mercury that are emitted from coal-burning facilities. A study on the most cost-effective modification of the EPA methods that would distinguish between the species of mercury in the emissions need not be unduly expensive and should yield the desired results within a reasonable time.

A project of longer range could be aimed at the development of accelerated sampling and analysis methods that could lead to an automated continuous monitor for rapidly diagnosing malfunctions in the emissions clean-up process.

\section{A.5 REFERENCES CITED IN APPENDIX}

1. Siegel, M., 1991, Clean Air Act Amendments 1990: Executive Summary, American Institute of Chemical Engineers, New York, N.Y.

2. Boutacoff, D., 1991, "New Focus on Air Toxics--The Clean Air Act," EPRI Journal, 16(2):4-13.

3. Radian Corporation, 1989, Estimating Air Toxic Emissions from Coal and Oil Combustion Sources, U.S. Environmental Protection Agency Report EPA-450/289-001, April.

4. Windholz, M., et al., Eds., 1976, The Merck Index, 9th Ed., Merck \& Co., Rahway, N.J., Monograph No. 3239, p. 432.

5. Lindberg, S.E., 1980, "Mercury Partitioning in a Power Plant Plume and its Influence on Atmospheric Removal Mechanisms," Atmosphere and Environment, 14:227-231.

6. Germani, M.S., and W.H. Zoller, 1988, "Vapor-Phase Concentrations of Arsenic, Selenium, Bromine, Iodine, and Mercury in the Stack of a Coal-Fired Power Plant," Environmental Science and Technology, 22(9):1079-1085.

7. 40 CFR Part 61, Appendix B, pp. 164-181.

8. Linch, A.L., R.F. Stalzer, and D.T. Lefferts, 1968, "Methyl and Ethyl Mercury Compounds--Recovery from Air and Analysis," American Industrial Hygiene Association Journal, 29(1):79-86.

9. Braman, R.S., and D.L. Johnson, 1974, "Selective Absorption Tubes and Emission Technique for Determination of Ambient Forms of Mercury in Air," Environmental Science and Technology, 8(12):996-1003. 
10. Ballantine, D.S., Jr., and W.H. Zoller, 1984, "Collection and Determination of Volatile Organic Mercury Compounds in the Atmosphere by Gas Chromatography with Microwave Plasma Detection," Analytical Chemistry, 56:1288-1293.

11. Zuo, Y., and S. Pang, 1985, "Determination of Dialkylmercury Compounds by Reaction Gas Chromatography," Fenxi Huaxue, 13(12):890-5 (Chinese; in Chemical Abstracts, 105:17605k).

12. 40 CFR Part 60, Appendix A, pp. 685-709.

13. Osmond, G., et al., 1988, Methodology for the Determination of Trace Metal Emissions in Exhaust Gases from Stationary Source Combustion Processes, U.S. Environmental Protection Agency, Environmental Monitoring Systems Laboratory, Research Triangle Park, N.C., EPA Contract No. 68-02-4119.

14. Mitchell, W.J., et al., 1979, Test Methods to Determine the Mercury Emissions from Sludge Incineration Plants, U.S. Environmental Protection Agency Report EPA600/4-79-058, Office of Research and Development, Research Triangle Park, N.C.

15. Junk, G.A., and B.A. Jerome, 1983, "Sampling Methods for Organic Compounds in Stacks," American Laboratory, pp. 16-29, Dec.

16. Cooke, M., F. DeRoos, and B. Rising, 1984, Hot Flue Gas Spiking and Recovery Study for Tetrachlorodibenzodioxins (TCCD) Using Modified Method 5 and SASS Sampling with a Simulated Incinerator, U.S. Environmental Protection Agency Report EPA-600/2-84-159, Oct.

17. Leutzen, D.E., et al., 1978, IERL-RTP Procedures Manual: Level 1 Environmental Assessment, 2nd ed., U.S. Environmental Protection Agency Report EPA-600/778-201.

18. Zaromb, S., et al., 1991, "High-Throughput Liquid-Absorption Air and Aerosol Sampler," International Symposium on Measurement of Toxic and Related Air Pollutants, Durham, N.C., May 6-10.

19. Bzezinska, A., et al., 1983, "A Study of the Determination of Dimethylmercury and Methylmercury Chloride in Air," Spectrochimica Acta, 38B(10):1339-1346.

20. Paudyn, A., and J.C. Van Loon, 1986, "Determination of Organic Forms of Mercury and Arsenic in Water and Atmospheric Samples by Gas Chromatography-Atomic Absorption," Fresenius Z. Analytical Chemistry, 325(4):369-376 (in Chemical Abstracts, 106; 12060q).

21. Jiang, G., et al., 1989, "Determination of Organomercurials in Air by Gas Chromatography-Atomic Absorption Spectrometry," Journal of Analytical Atomic Spectrometry, 4(4):315-318 (in Chemical Abstracts 111:179888f). 
22. Bloom, N., and W.F. Fitzgerald, 1988, "Determination of Volatile Mercury Species at the Picogram Level by Low-Temperature Gas Chromatography with Cold-Vapour Atomic Fluorescence Detection," Analytica Chimica Acta, 208:151-161.

23. Takizawa, Y., K. Minigawa, and M. Fujii, 1981, "A Practical and Simple Method in Fractional Determination of Ambient Forms of Mercury in Air," Chemosphere, 10(8):801-809.

24. Schroeder, W.H., and R. Jackson, 1984, "An Instrumentai Analytical Technique for Vapour-Phase Mercury Species in Air," Chemosphere, 13(9):1041-1051.

25. Schroeder, W.H., and R.A. Jackson, 1985, "An Instrumental Analytical Technique for Speciation of Atmospheric Mercury," International Journal of Environmental Analytical Chemistry 22(1-2):1-18 (in Chemical Abstracts, 104:94390t).

26. Dogan, S., and W. Haerdi, 1978, "Preconcentration on Silver Wool of Volatile Organo-Mercury Compounds in Natural Air and the Determination of Mercury by Flameless Atomic Absorption Spectrometry," Journal of Environmental Analytical Chemistry, 5:157-162.

27. Tomita, T., et al., 1987, "Basic Studies on a Method for Fractional Determinations of Mercury Compounds in Air," Aichi-ken Kogai Chosa Senta Shoho, 15:19-26 (in Chemical Abstracts, 112:41589y).

28. Pang, S., G. Qiu, and L. Xu, 1984, "Selective Absorption Tube and Cold-Atomic Absorption Technique for Rapid Determination of Mercury Species in Air," Fenxi Huaxue, 12(7):564-568 (in Chemical Abstracts, 102:66589e).

29. Kobayashi, Y., 1983, "Separation and Analysis of Mercury Compounds in Environmental Air," Kanagawa-ken Taiki Osen Chosa Kenkuy Hokoky, 25:63-69 (in Chemical Abstracts, 104:23531d).

30. Takizawa, Y., et al., 1981, "Studies on Mercury Behavior in Man's Environment. 5. Photodegradation of Methylmercury in the Atmosphere by Ultraviolet Rays with Sterilization," Nippon Koshu Eisei Zashi, 28(7):313-320 (in Chemical Abstracts, 96:57019z).

31. Sibbelt, D.J., R.H. Moyer, and T.R. Quinn, 1975, "Improvement of Instrumentation and Methodology for Collection and Analysis of Mercury," NTIS PB Report No. 242295 (in Chemical Abstracts, 84:34811q).

32. Henriques, A., and J. Isberg, 1975, "New Method for Collection and Separation of Metallic Mercury and Organomercury Compounds in Air," Chemistry Series, 8(4):173-176 (in Chemical Abstracts, 84:110743m). 

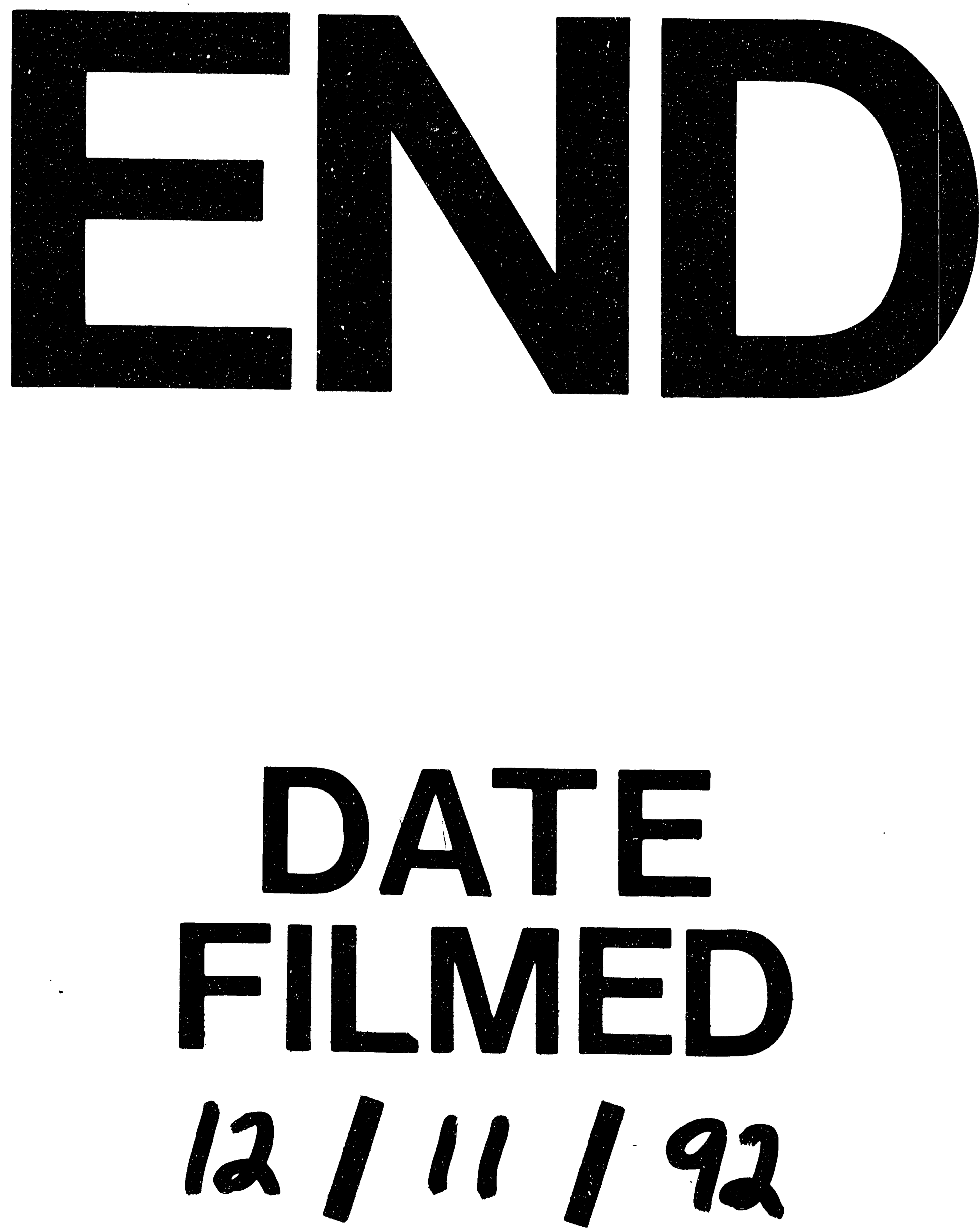

1 
